\title{
Clinical psychology of religion: A training model
}

\author{
By Marinus van Uden, Jos Pieper
}

\begin{abstract}
In this paper we will show you a part of a course "Clinical Psychology of Religion" that has been developed in the Netherlands for introducing mental health professionals in the field of clinical psychology of religion. Clinical psychology of religion applies insights from general psychology of religion to the field of the clinical psychologist. Clinical psychology of religion can be defined as that part of the psychology of religion dealing with the relation between religion, worldview and mental health. Like the clinical psychologist, the clinical psychologist of religion deals with psychodiagnostics and psychotherapy, but concentrates on the role religion or worldview plays in mental health problems. The relation between religion and mental health has been a subject for study since the start of the psychology of religion at the end of the last century. A number of authors have elaborated on the ways in which religion can be beneficial or detrimental to psychological health. In recent research we have found that there is a great need among psychotherapists to become better equipped in this field.
\end{abstract}

\section{Introduction}

In a review of 10 years (1984-1994) research on religion and psychotherapy Worthington et al. (1996) indicate that, since 1986, interest in religion and counseling has boomed. In the last few years in the Netherlands the interest in the relation between meaning-giving, worldview and religion on the one hand, and social and mental health care on the other, is also growing.

What does this mean for the praxis of mental health care in the Netherlands?

Two central premises are found. In the first place, one agrees that religion and worldview could and should have a prominent place in many psychotherapeutic interventions. The physical, emotional, behavioural and social problems which the client brings in are often related to his meaning-givingsystem and religious attitudes. At the same time, psychotherapists are then accused of neglecting this dimension. Some authors, especially those who stand close to the humanistic tradition, are particularly concerned about worldview in general (Dijkhuis, Mooren, 1988). Others, especially those who stand close to the Protestant tradition, are especially concerned over the religious values of the clients (Schilder 1991; Van der Wal, 1991). In the latter group there are also authors who argue that pastoral workers should be working in the institutions for regional ambulatory mental health care (the socalled Riagg), and even authors who plead for founding new regional ambulatory mental health care institutions based on Christian principles, of which the Gliagg is an example. 
Representatives of Riagg nevertheless disagree with this last premise. They state that, even in the very religious regions of the Netherlands, there are enough Riagg therapists with sufficient expertise in the religious background of the clients.

How do these Riagg and Gliagg therapists themselves evaluate the place of religion/worldview in their own life and practice?

Let us summarize the main conclusions from our research (Pieper,Van Uden, 1998a, b; Schuurman, Van Uden, Pieper, 1999; Van Uden, Pieper, 2000) into these matters.

1. With regard to the religious background of the Riagg-therapists, the following conclusion may be drawn. Compared with the average Dutch citizen, therapists believe less in God and have a lower weekly church attendance rate. The response-rate of $49 \%$ is also an indication that the research-topic is not particularly interesting for the therapists of these non-religious Riaggs. From the Gliagg, the response was $76 \%$.

For the Gliagg-therapists faith is a fundamental value. They all believe in God and go to Church at least once a week.

2. With regard to the relation between religion/worldview and mental problems, the following conclusions may be drawn. Earlier research (Pieper, Van Uden, 1996; Van Uden, Pieper,1996,1998) had shown that $40 \%$ of the clients report a relationship between these two variables. Riagg therapists report seeing such a relationship with only $18 \%$ of the clients.

The Gliagg therapists report this relationship in $67 \%$ of their clients. With regard to the kind of relationship, we can conclude that clients themselves point more to the positive influence of religion/worldview than the Riagg therapists.

Of the Riagg therapists who see a relation, half of them see a positive one, half of them a negative one. The Gliagg therapists, on the other hand, point more to the positive influence of faith.

3. With regard to the actual treatment of religious/worldview aspects of mental problems, it may firstly be said that most Riagg therapists claim to examine these aspects. But at the same time, half of them are not confident about their skills for treating these aspects and this leads to a need for extra training (46\%). Specific religious techniques are hardly used.

All Gliagg therapists say they deal with the religious/worldview aspects of mental problems and use several religious techniques. $41 \%$ of them pray privately for the client. $80 \%$ feel confident about their skills in dealing with religious problems. $57 \%$ would still, however, like extra training in this field.

4. Contacts between Riagg therapists and the clergy are rather few. Referral occurs in only about $1 \%$ of the cases. With the Gliagg, the contacts are substantial. The Gliagg therapists know how to contact the clergy and have confidence in their competence.

In this context, the most relevant point is the fact that $46 \%$ of the Riagg therapists state that they would like to receive extra training in the area of religion and worldview, while even $57 \%$ of the Gliagg-therapists state the same thing. 


\section{The course}

In this paper we will show you a part of a course, "Clinical Psychology of Religion", that has been developed in the Netherlands for introducing mental health professionals to the field of clinical psychology of religion.

The aim is to help these professionals to acquire more specific knowledge of several ways in which mental health problems are related to religion or worldview in general. The aim of the course is to prepare them for activities in those fields where clients turn to professionals for help in understanding and solving psychological problems related to meaning, religion and worldview.

More specifically, the course aims at three objectives:

1. the mental health worker should acquire specific knowledge with respect to theories and concepts that help to conceive the search for meaning in life as a cognitive appraisal process, how religion and other socio-cultural systems are involved in this process, and how meaning construction is related to self-esteem, subjective well-being, and psychopathology.

2. the mental health worker should acquire theoretical competence to relate clinical psychological theories and concepts to the field of religion and theories and concepts of the psychology of religion to behavioral phenomena in the domain of psychopathology and mental health.

3. the mental health worker should acquire basic practical skills for working in a mental health care unit, as a professional focussed on mental health problems which obviously, or presumably, are related to religion.

The content of the course deals with clinical psychology of religion. Just like the clinical psychologist, the clinical psychologist of religion deals with psychodiagnostics and psychotherapy. He is focussed, however, on the role of religion or worldview in mental health problems. Clinical psychology of religion applies the knowledge of general psychology of religion to the field of the clinical psychologist. Psychological processes, such as projection, rationalisation and other defence mechanisms serving to overcome anxiety, have always been expressed in various forms of religious behaviour (dogmatism, intolerance, taboos, utopia's, and so on). Anxiety is one of the roots of religiosity. Another root lies in the basic human experience of the search for meaning. In spite of the destabilisation of overarching frameworks of meaning and the marginalisation of church religion, these psychological structures remain active and become manifest in more secularised ways.

To summarise: clinical psychology of religion is involved (a) in pathology that is expressed in religious phenomena, and (b) in the search for meaning. When people are disintegrated as a consequence of serious illness or other traumatic events, a re-appraisal of the meaning of life is necessary for the recovery of psychological well-being. Clinical psychology of religion can be described as that part of the psychology of religion that is specifically involved in the relation between religion, worldview, and mental health. 
Let us now introduce you to the principles of the specific method, the so-called problem oriented education procedure, we used to unfold the field of clinical psychology of religion.

\section{Principles and characteristics of problem oriented education}

Who among you is unfamiliar with the situation where someone asks you about something you should know (ready knowledge, previously learned material). You know that you know it. You can visualize the pages in the book or the words on the board in front of you. Yet the knowledge is not ready, you cannot answer.

In some professions there is not enough time to look up the answers in the literature. Nor is it always easy to reason properly about problems. Which approach is best? In practice, a problem is often more complicated than the approach of one discipline would lead you to expect.

Academic education developed problem oriented education (POE) as a solution to this sort of situation. Since its introduction in 1969 at McMaster University in Hamilton, Canada, problem oriented education has been implemented by many universities and institutes of higher learning. In the Netherlands, for example, all the study programs at the University of Maastricht in the Netherlands are in 'Problem Oriented' form.

\subsection{Problem Oriented Education Starting points}

In problem oriented education, acquiring and applying specialized knowledge go hand in hand. This makes your specialized knowledge accessible and usable.

This goal is reached by using assignments as a teaching tool. Assignments consist of carefully selected problem situations that describe phenomena or events which you may have to confront in your professional life.

An assignment encourages you to ask what you would do in that case, or what you would think about it. Almost automatically you search your thoughts for similar situations or events that you may have experienced and for concepts you can use to analyse the event or phenomenon. You are activating your prior knowledge. You are also directing your own learning process: you are linking the professional knowledge your are acquiring to your present knowledge and interests.

Working out assignments and learning with the help of described phenomena or events (problem situations) is not something you do alone. You discuss the assignment in a study group following a procedure known as the 'zevensprong' ('jumping in seven steps', named after an old folk dance). You articulate the problem together, analyse it using what you, as a group, already know, and formulate questions for study. Using these questions, each group member studies the literature individually, trying to reach a solution or a more precise formulation of the problem. The results are discussed in the study group chaired by one group member. Together you treat the problem and draw conclusions. The study 
group is led by a tutor. This is the lecturer's role. The tutor directs the discussion and learning process only when necessary. While working on the assignment you get direct feed-back from your fellow group members and tutor on your progress.

In short, you work in a study group and in independent study activities on assignments in which a problem is formulated that is to serve as a model for a whole spectrum of similar problems in your professional life. You apply what you learn immediately to the problem.

\subsection{Method}

In problem oriented education one receives several assignments. These are intended to develop skills and to apply them immediately. Each assignment (via a text, a film or video) describes, or refers to, a situation you could meet in your professional life.

It is not immediately clear what the problem is, let alone what the solution is, at least no 'professional' solution that does justice to the complexity of the problem.

You analyse the problem and suggest possible solutions. You are expected to have an active and independent study attitude where, with other group members, you analyse the problem and develop a usable expertise to 'handle' such problems.

One tool for learning to approach problems systematically and scientifically is the 'zevensprong'. It is a step-by-step method to solve problems that arise, or to better define them.

\subsection{The 'Zevensprong'}

Before joining the study group, you study at home the assignment that will be discussed at the meeting. You examine it in the light of the following questions, making notes that you can use during the study group meeting:

- What are the essential points described or raised in the problem situation?

- What, in your opinion, is the formulated or to-be-formulated problem in this assignment?

- For which important or difficult concepts have you been unable to find a meaning?

Steps 1 to 5 take place in the study group as preparation for the assignment, i.e. as preparation for step 6, independent study, and step 7, return to the ('improved' and more professional) statement of the problem. 


\section{Step 1 Confrontation with the Assignment}

tasks: A first exploration. Description of difficult concepts. Extracting the important points from the assignment. To reach, as a group, a first provisional working definition.

\section{Step 2 Formulating the Problem}

tasks: A concise formulation of the problem that, in the group's view, is present in this assignment. This formulation should include all the important points (see step 1) present in the assignment.

Articulate the problem as a question to be investigated, not to be judged.

\section{Step 3 Analysing the Problem}

tasks: Brainstorming over the elements that could play a role in analysing the problem. Each group member participates, applying his/her previously acquired knowledge.

\section{Step 4 Stock-taking}

tasks: The structuring (stock-taking and ordering) of factors that play a role in the problem (brainstorming phasc) and that offer material for a possible explanation or illumination of the problem.

\section{Step 5 Formulating Learning Goals}

tasks: Drafting study questions to use in treating the problem. Study questions refer to concepts whose working definitions have been agreed upon, to relations between factors which may explain or illuminate the problem.

\section{Step 6 Independent Study}

Guided by the problem's formulation and the study questions, you select and study the relevant literature. You make notes so that

a) your study questions are answered

b) using the literature studied and your notes you can treat the problem formulated.

In this way, you prepare for the following meeting of the study group, where the assignment will be discussed further.

tasks: Targeted examination of the literature using the study questions; preparation for treating the problem in the study group.

\section{Step 7 Returning to the Problem}

tasks: This step takes place during the next study group meeting.

Treatment of the problem using the results of independent study (step 6). This means confronting the results of your independent study with the (provisional) formulation of the problem (step 2) and with the interpretations / study results of your group members. 


\subsection{The study group}

It is customary for one meeting to precede the assignment and one to follow it. Each discussion of each assignment, both those preceding and those following it, is led by a chairperson. The group members take turns in fulfilling this function.

Before each discussion a secretary is appointed to write the important points on a board.

In principle, neither the chairperson nor the secretary plays an active role in contributing to the content of the discussion. The tutor, normally a lecturer, is watching over, guiding and advancing the content of the discussions. This role does not take the form of actively contributing to the content.

\section{Clinical psychology of religion by eight assignments}

In our course we unfold the field of clinical psychology of religion by means of eight successive learning assignments. In the problem oriented education procedure the learning assignments are completed over a period of 9 meetings. In the first three assignments ('religion and mental health', 'mystical experience and psychopathology' and 'religion and depression'), the focus is on the relation between religion and mental health/illness. This is discussed first in a general way, then a religious phenomenon (the mystical experience) is approached from the perspective of mental illness, then a psychological disturbance (depression) is related to specific religious belief structures. In the fourth assignment (projection), the basic question is discussed of whether or not religiosity can be reduced to psychological processes. Is religion merely projection or is it more? In the fifth assignment we deal with religious imagination. In the sixth, religion as a coping device is dealt with. The last two assignments ('religious countertransference' and 'psychotherapy and pastoral care') are practice-oriented and focus on the treatment of religious problems in mental health care.

So we have the following topics: 1 . Religion and mental health; 2 . Mystical experience and psychopathology; 3. Religion and depression; 4. Projection; 5. Religious imagination; 6 . Religion as a coping device; 7. Religious countertransference; 8. Psychotherapy and pastoral care.

\subsection{An illustration of one assignment}

Let us now finish and illustrate the procedure by presenting one assignment. We selected the one on countertransference. The trigger with which the study group is confronted looks like this:
Assignment 7:
Religious Countertransference
Instruction:
Steps 1-5 of the "zevensprong"

Material:

A 42 year old female who is experiencing marital difficulties comes in for counseling at a counseling center. The client belongs to a small Baptist congregation in a semi-rural area; the counselor - who is also female - is divorced and now Episco- 
palian (formerly she was a member of a fundamentalist Bible Christian Church). Initially, the client asked for some coping mechanisms and ideas on how to communicate better with her husband. After a number of sessions, the severity and complexity of the problem came more fully to light. Consequently, the picture of the complaint, which was vague and introduced each time with a strong statement on the importance of the sacredness of a commitment to marriage, also became clearer.

In addition, the client began to describe certain changes in the family which were the source of additional pressure. Married at 18, she wanted to move out of her home, which was quite strict, and start a family of her own with a person whom she perceived as "strong". Initially the marriage seemed quite calm. When asked about this she noted that her traditional role of wife and mother made her feel fulfilled, and outside of occasional flare-ups by her husband, the match seemed "satisfactory". Most of her efforts were centered around the family and activities in the church.

In her late 30's several significant changes took place. The children, now grown up, moved out of the house.

Client (Cl): "I was so upset I didn't know what to do, so I went to the minister. I told him all about it and he seemed to be sympathetic."

Counselor (Co): "Seemed to be?"

Cl: "Well he was very sorry for me but said that it was God's will that I had this tribulation in my life and that I should pray very hard."

Co: "That didn't seem to be exactly what you hoped to hear from him, did you?" (Counselor is feeling furious at this point and would like to both point out - from her viewpoint - the terrible theology and lack of empathy in the minister's statement; her "gut feeling" is to say, "He's a jerk; why didn't you tell the chauvinist pig to go to hell!")

Cl: "Well no. I guess I expected him to tell me how to make the situation better somehow. But that's not the end of it. I then said to him that I didn't know how long I could take the abuse and that maybe I would have to separate from my husband. At that point he really got wild. He said that women were subject to their husbands and pulled out the Bible to show me where it was written. He said it was evil for me to even think that and I was avoiding my responsibilities as a Christian woman."

Co: (The counselor is now furious inside.) "How did you feel when he responded this way?"

Cl: "Well, I became frightened. I was also sad. I want to be a good wife. But it's so hard. I felt sort of guilty asking about the separation; I knew I was wrong, but it has been so hard." (Pause)

Co: (Counselor feels like rescuing client.) "So, you have had it so hard that you even thought of leaving your husband and you went to the minister for some support and instead he yelled at you."

Cl: "Yea. I hoped he would help me out of this mess. Now I feel like it's worse... (Client looks directly at counselor.) "Do you think I should leave my husband... I mean is it ok? I know you're not from my Church but do you think it's a sin?" 
Co: (Counselor feels like saying, "Of course it's no sin; the sooner you are away from that bastard and your small-minded minister, the better off you'll be!").

(From: R.J. Wicks. My values, your values: my defences, your defences: countertransference with clients of different religious denominations. Journal of Pastoral Counseling, 1985, 20, 47-52.)

Independent Siudy: $\quad$ Step 6 of the "zevensprong"

Returning to the Problem: Step 7 of the "zevensprong"

Literature relevant to this assignment:

J.H.N. Kerssemakers, Tegenoverdracht bij religieuze problematiek. In: J.H.N.

Kerssemakers. Psychotherapeuten en religie. Een verkennend onderzoek naar tegenoverdracbt bij religieuze problematiek. Nijmegen, Katholiek Studiecentrum, 1989, 31-38. A.J.R. Uleyn. Zingevingsvragen en overdrachtsproblemen in de psychotherapie. In: M. Kuilman, A.J.R. Uleyn. Hulpverlener en zingevingsvragen. Baarn, Ambo, 1986, 35-67.

\section{Recommended literature:}

P.W. Pruyser. Beoordeling van religieuze opvattingen van de patiënt in de psychiatrische gevalsstudie. In: P.W. Pruyser. Geloof en verbeelding. Essays over levensbeschouwing en geestelijke gezondheid. Baarn, Ambo, 1992, 56-63.

E.P. Shafranske, H. Newton Malony. Clinical Psychologists' Religious and Spiritual Orientations and their Practice of Psychotherapy. Psychotherapy, 1990, 27, 72-78.

R.J. Wicks. My values, your values: my defences, your defences: countertransference with clients of different religious denominations. Journal of Pastoral Counseling, 1985, 20, 47-52.

I.D. Yalom. Nietzsches tranen. Amsterdam, Balans, 1995.

\section{Concluding}

We hope that we have been able to make clear to you that this procedure is able to stimulate study in the field of clinical psychology of religion in a fresh way, especially for workers in the field of mental health care, who are rather distant from religious issues. Research as to the actual effects of the course is yet to be done, but we are quite optimistic. In our experience, this procedure and course was able to (re-?)create an intrinsic interest in religious matters among these highly secularised professionals. Apart from this, another effect was that several of the groups of participants became quite intimate and began to function as intervision groups on religious and worldview topics in psychotherapy.

\section{Literature}

Dijkhuis, J.H., Mooren, J.H.M. (1988): Psychotherapie en levensbeschourving. Baarn: Ambo.

Pieper, J.Z.T., Uden, van M.H.F. (1996): Religion in mental health care: Patients' views. In: P.J. Verhagen \& G. Glas (eds.) Psyche and Faith. Beyond Professionalism. Zoetermeer: Boekencentrum, 69-83. 
Pieper, J.Z.T., Uden, van M.H.F. (1998a): Riagg-therapeuten over geloof en levensbeschouwing. In: Jacques Janssen, Rien van Uden en Hans van der Ven (red.) Schering en inslag. Opstellen over religie in de bedendadgse cultuur. Nijmegen: KSGV, 52-74.

Pieper, J.Z.T., Uden, van M.H.F. (1998b): Religieuze hulpverlening. Gliagg-therapeuten over geloof en levensbeschouwing. In: M. van Uden \& J. Pieper (red.). Wat baat religie? Godsdienstpsychologen en godsdienstsociologen over bet nut van religie. Nijmegen: KSGV, 47-66.

Schilder, A. (1991): Eigen over- of ongevoeligheden t.a.v. een christelijke levensbeschouwing. In: Filius, R., Visch, M. (red.) Zin in welzijn. Over levensbeschouwing en professionaliteit in bet welzijnswerk. Zwolle: Windesheim, 41-49.

Schuurman,I., Uden, van M.H.F., Pieper, J.Z.T. (1999): Meer licht op levensbeschouwing in therapie. Een kwalitatief onderzoek naar levensbeschouwing onder Gliagg- en Riagg-therapeuten. Psyche en geloof. Tijdschrift van de Christelijke Vereniging voor Psychiaters, Psychologen en Psychotherapeuten, 10, 100-115.

Uden, van M.H.F., Pieper, J.Z.T. (1996): Religie in de geestelijke gezondbeidszorg. Nijmegen: KSGV.

Uden, van M.H.F., Pieper, J.Z.T. (1998): Geloof en levensbeschouwing in de geestelijke gezondheidszorg. In: G. Glas (red.). Psychiatrie en religie. De bijna verloren dimensie. Nijmegen: KSGV, 75-97.

Uden, van M.H.F., Pieper, J.Z.T. (2000): Religion in mental health care: Psychotherapists' views. Archiv für Religionspsychologie, 23, 264-277.

Wal, van der J. (1991): Principes en praxis van gereformeerde bulpuerlening, Lezing op studiemiddag 'Riagg en geloof'. Tiel, 1991.

Worthington, E.L. Jr., Kurusu, T.A., McCullough, M.E., Sandage, S.J. (1996): Empirical Research on Religion and Psychotherapeutic Processes and Outcomes: A 10-year Review and Research Prospectus. Psychological Bulletin, 119, 448-478. 